REPRINTED FROM:

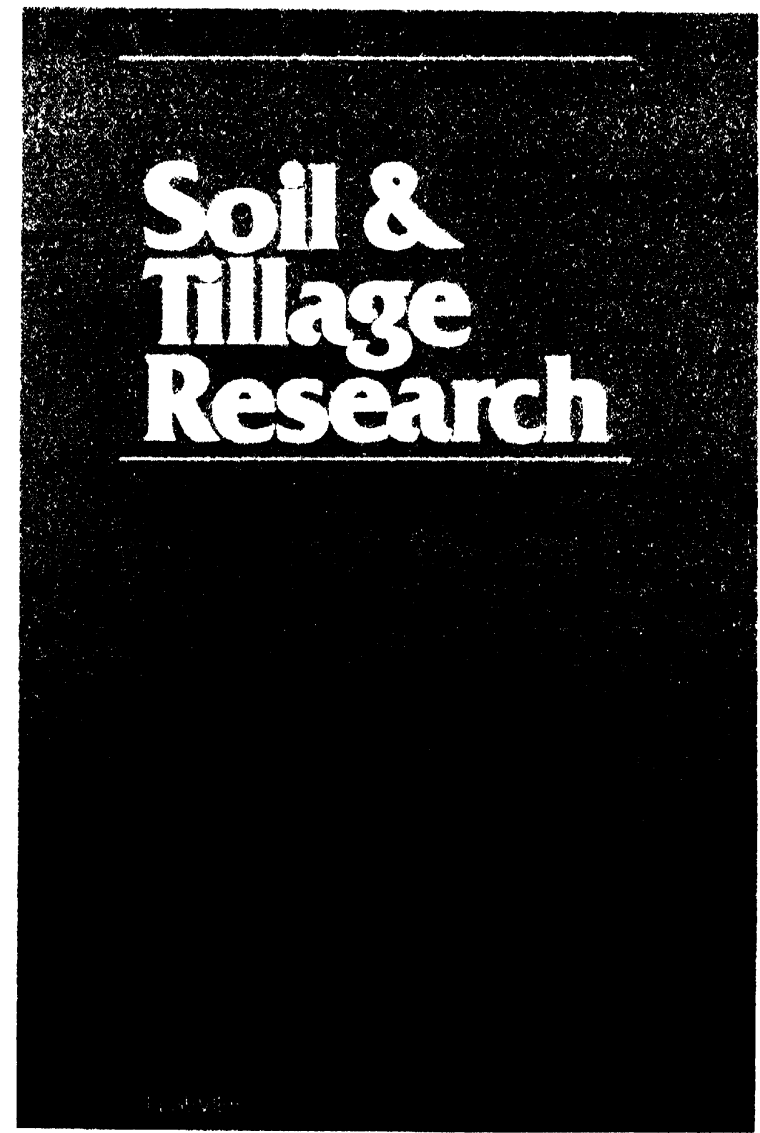

ELSEVIER SCIENCE PUBLISHERS, AMSTERDAM 


\section{Soil \& Tillage Research}

An International Journal on Research and Development in Soil Tillage and Field Traftic, and their Relationships with Soil Environment, Land Use and Crop Production

\section{Editor-in-Chiof}

C. VAN OUWERKERK

Secretary-General of ISTRO

Institute for Soil Fertility

P.O. Box 30003

9750 RA HAREN GN

The Netherlands

\section{Essociate Editors}

R.R. Allmaras, Pendleton, OR, U.S.A.

W.B. Voorhees, Morris, MN, U.S.A.

\section{Editorial Advisory Board}

Chairman

W.E. Larson,St. Paul, MN, U.S.A.

A. Canarache, Bucharest, Romania

R.Q. Cannell, Wantage, Great Britain

G. Chisci, Florence, Italy

W. Ehlers, Göttingen, F.R.G.

M. Estler, Freising-Weihenstephan, F.R.G.

E.L. Greacen, Glen Osmond, S.A., Australia

A. Hadas, Bet Dagan, Israel

L Henriksson, Uppsala, Sweden

J. Kampen, Washington, DC. U.S.A.

G. Keçecioglu, Bornova-Izmir, Turkey

J.W. Ketcheson, Guelph, Ont., Canada

$H$. Kuipers, Wageningen. The Netherlands

R. Lal, Ibadan, Nigeria

J. Luis Hernanz, Madrid, Spain

J.V. Mannering, West Lafayette, IN. U.S.A.
Published in Collaboration with the International Soil Tillage Research

Organization (ISTRO)
E. McKyes, Ste. Anne de Bellevue, Que., Canada

V. Mihalić, Zagreb, Yugoslavia

G. Muchiri, Nairobi, Kenya

O. Muzilli, Londrina, PR, Brazil

D.R. Nielsen, Davis, CA, U.S.A.

A. Njøs, As-NLH, Norway

B.S. Pathak, Ludhiana, India

J. Sakai, Hakozaki, Higashi-ku, Fukuoka, Japan

R.L. Schafer, Auburn, AL U.S.A.

J. Simon, Prague, Czechoslovakia

R.E.H. Sims, Palmerston North, New Zealand

B.D. Soane, Penicuik, Midlothian, Great Britain

H.M. Taylor, Ames, IA, U.S.A.

A. Vez, Nyon, Switzerland 


\title{
SOIL CRUST AND ITS IMPACT ON CROP ESTABLISHMENT: A REVIEW
}

\author{
N.K. AWADHWAL and G.E. THIERSTEIN \\ International Crops Research Institute for the Semi-Arid Tropics (ICRISAT), Patancheru. \\ Andhra Pradesh (India)
}

(Accepted 18 February 1985)

\begin{abstract}
- Awadhwal, N.K. and Thierstein, G.E., 1985. Soil crust and its impact on crop establishment: a review. Soil Tillage Res., 5: 289-302.
\end{abstract}

Soil crusting is a worldwide problem occurring under a wide range of soil and climatic conditions. Soil crusts affect seedling emergence and reduce the infiltration rate causing loss of water and crop yield. Considerable research has been done in order to understand the process of crust formation and the factors affecting it. Soil crust strength and impedance to seedling emergence have been studied in detail and measures to avoid crusting and methods to ameliorate its adverse effects have been suggested. The findings of such studies are summarized in this paper.

\section{INTRODUCTION}

The successful establishment of a uniform stand of a desired density is an important phase of crop production. Crop-stand establishment is adversely affected by poor emergence of seedlings due to soil crusts. The problem of soil crusting or capping is worldwide; it occurs under a wide range of climatic conditions. In many arid and semi-arid regions soil crusting is quite common, especially on sandy and loamy soils. In these regions, the rapid drying of soil enhances the development of soil crust (Carnes, 1934; Isiumov, 1938; Hillel, 1959, 1960; Taylor, 1962; Williams, 1963; Heinonen, 1965; Cary and Evans, 1974; Miller and Gifford, 1974; Prihar, 1974; Gupta and Yadav, 1978; Hoogmoed, 1980). Sometimes the crust restricts the emergence of seedlings completely and makes replanting necessary. The effects of the crust can be serious when a crust is formed around the base of the seedling after emergence and causes the loss of the seedling by girdling (Arndt, 1965a). Crust on the soil surface, in combination with high intensity rainfall, causes large losses of rain water by run-off. Even in years when rainfall is sufficient for crop production, poor yields may be encountered due to shortage of water held in soil.

Soil crusting and seedling emergence has been widely researched; however, an inventory of the available information pertaining to its various aspects is lacking. In this review, information about formation of soil crust, its physical 
characteristics, impedance to seedling emergence, methods of crust management as well as measures of encouraging emergence through the crust have been gathered and discussed, in order to provide an insight into the problem of soil crusting and its impact.

\section{SOIL CRUST FORMATION}

A soil crust is a thin hard layer formed on the surface of the soil due to dispersive forces in rain drops or irrigation water followed by drying. The physical mechanism of crust formation can be summarized as follows. Due to wetting and impact of raindrops the soil aggregates slake, and small particles, like clay and silt attached to larger grains (sand) get separated and disperse at the soil surface. These small particles form a suspension in the water and move within the top layer through the voids between grains, because of the capillary suction from the underlying layers. The voids become choked with fine particles and a thin layer is formed at the surface Densification of the soil surface layer during wetting and subsequent drying is enhanced due to: tendency of the platey particles, in a state of semisuspension, to settle with their long axis in a horizontal direction; attraction among adjoining particles; retreat of water held in space between particles during drying. Cementation of the surface layer takes place due to reorientation of particles and precipitation of calcium carbonate during the drying process (McIntyre, 1958b; Hillel, 1960; Epstein and Grant, 1967, 1973; Morin et al., 1981).

According to McIntyre (1958a), the crust consists of 2 parts; an upper skin-seal, attributed to compaction due to raindrop impact, and a deeper washed-in region of decreased porosity attributed to fine particle movement and accumulation. He found that the thickness of the skin-seal and the washed-in zone were $0.1 \mathrm{~mm}$ and $2.0 \mathrm{~mm}$, respectively. The washed-in layer was formed only in soils that were easily dispersed. However, in the case of sandy loam loessial soils, Chen et al. (1980) did not find any significant downward movement and accumulation of fine particles in the $0.1-2.8-\mathrm{mm}$ zone. They classified soil crusts into 2 categories: (1) structural crusts; (2) depositional crusts. The formation of these different types of crusts is described in the following sections.

\section{Formation of a structural crust}

Structural crusts are formed as a result of water-drop impact. In the initial stage the prewetted soil contains large sand particles covered quite uniformly with fine particles all over their surface in the upper layer (0-3 $\mathrm{mm}$ ). Later, when run-off starts, the sand particles get stripped of the fine material, and large naked sand particles are exposed at the top of the soil. The morphology of the soil at a depth greater than $0.1 \mathrm{~mm}$ still remains the same as in the prewetted soil. During the final formation stage, due to 
continued rain, the sand particles at the top of the soil get removed and a dense thin "skin" of 0.1-mm thickness, composed mainly of fine particles, is formed at the soil surface.

\section{Formation of depositional crust}

These are formed by translocation and deposition of fine soil particles. The thickness of the crust equals the upper layer of soil which tends to peel off spontaneously when the soil dries out. This type of crust is also characterized by the presence, at the surface of the soil, of a thin 'skin' about 0.1 $\mathrm{mm}$ thick. No sand particles are present in the skin suggesting that its texture is completely different from that of bulk soil. Larger sand particles typical of the bulk soil are observed at the $4-5 \mathrm{~mm}$ depth, which is where the crust gets spontaneously separated from the bulk soil.

\section{Simulation of soil crust}

Simulation of soil crust is generally done to study its effect on seedling emergence, infiltration, and run-off (Tackett and Pearson, 1965; Busch et al., 1973). A wide range of sprinkling devices were found unsuitable because of pattern effects during calm conditions, and drift with wind (Arndt, 1965a). Rainfall simulators have been designed to approximate drop size and distribution, velocity of drops, and intensity of a rain storm. These are used to produce a soil crust under varied rainfall intensities, duration and drying conditions. The rainfall simulator can create a crust repeatedly and precisely with the same characteristics when desired. Precision in simulation is needed for accurate results. Holder and Brown (1974) reported that the different durations of rainfall at similar intensities resulted in larger differences in the impedance of crust than did different intensities for the same duration.

\section{PHYSICAL CHARACTERISTICS OF CRUSTS}

Soil crusts are characterized and distinguished by their greater mechanical strength, markedly low porosity, higher bulk density, lower degree of aggregation, higher amount of silt and clay, and higher value of cation exchange capacity as compared to that of underlying bulk soil (Lemos and Lutz, 1957; Hillel, 1959; Sharma and Agarwal, 1980).

A number of investigators have studied the hydraulic characteristics of soil crust. It reduces the infiltration rate that leads to higher run-off and reduction in the amount of water stored in the soil. The hydraulic conductivity of the deep layers of a virgin soil were found to be about 800 times higher than that of the skin seal. In addition, in wet conditions, the crust reduced the gaseous permeability of soil, leading to seedling respiration problem. (McIntyre, 1958a; Rose, 1962; Evans and Buol, 1968; Epstein and Grant, 1973; Falayi and Bouma, 1975). 


\section{Factors affecting crust strength}

Crust strength is affected by its own moisture content and thickness, rate of drying, rainfall intensity and duration, soil texture, type of clay and bulk density. The mechanical composition of the surface soil, wettingdrying and puddling as well as the frequency and width of cracks that form as a result of drying play an important role in determining the strength of crust (Hanks and Thorp, 1957; Lemos and Lutz, 1957; Taylor, 1962; Arndt, 1965a; Qashu and Evans, 1967). A harder and less permeable soil crust develops under the following conditions (Hillel, 1960; Hanks, 1960): (1) the initial bulk density of the top soil is higher; (2) the soil does not contain organic matter and its clay content is higher; (3) the soil aggregates at the surface are smaller prior to wetting; (4) the top layer water content is higher and maintained for longer time (slower drying).

Holder and Brown (1974) found an inverse relationship between mechanical impedance and percentage moisture content of the crust between 2.8 and $20 \%$ moisture. The maximum impedance occurred in the narrow rangd of 2.2-2.8\% moisture. A decrease in impedance associated with crust cracking was observed at the moisture content below this range. Hadas and Stibbe (1977) found an exponential relationship between crust strength $(S)$ and moisture content $(P w)$ and expressed it as:

$S=B \exp (-A P w)$

Where $A$ and $B$ are constants and both depend on rainfall intensity, total amount of rain and drying rate. $B$ is also influenced by soil physical characteristics. They observed that the natural crust resistance to penetration was greater for the crust that was formed on disked plots than ploughed plots on the soils ranging from silty sand to silty clay.

\section{Measurement of crust strength}

Modulus of rupture, as described by Richards (1953), has been widely used as an index of soil crust strength in relation to seedling emergence. Arndt (1965a) observed that due to variation in the width and thickness of the crust samples the value of modulus will vary from sample to sample. The field samples will be irregular in shape, so the estimation of their dimension will involve some error that will affect the calculation of modulus. Since there is no known way of equating the breaking load or the modulus of rupture of free samples with seedling force, it seems much easier to measure the impedance directly than to seek the additional information needed to apply the modulus of rupture approach. Barley and Greacen (1967) also made similar observations and suggested relating emergence directly to the force required to break the crust.

Mechanical probes have been used by many investigators to simulate the actual seedlings without accounting for the characteristic differences in them 
to measure the force required for emergence, by pushing the probe upwards through the soil (Morton and Buchele, 1960; Stout et al., 1961). Arndt $(1965 a, b)$ designed an instrument that measured the force required for emergence of a mechanical probe through crust in the field. The instrument was buried in a chamber in the field prior to the formation of surface crust. Holder and Brown (1974) modified this method for measuring crust impedance in the laboratory. They used a probe supported by a balance that was raised by means of a jack. Soil was placed in boxes which were equipped with guide tubes to allow the probe to penetrate the soil crust from below. These techniques proved to be crude and laborious. Goyal $(1979,1982)$ included all the pertinent properties of the soil-seed system in a simulation study and developed an equation for the seedling emergence force of soy. bean as the seedling penetrates vertically through a crusted soil.

\section{IMPEDANCE TO SEEDLING EMERGENCE}

Soil crust impedes the emergence of young seedlings even when other factors like availability of moisture, oxygen, soil temperature and planting depth are not limiting. The crust poses a serious problem to small seeded crops, and inhibits emergence of even large seeds such as corn which normally have strong emergence force. Usually the crops affected by crusting are pearl millet (Pennisetum americanum L.), cotton (Gossypium hirsutum L.) grain sorghum (Sorghum bicolor L.), soybean (Glycine max L.), guar (Cyamposis tetragonoloba), carrot (Daucus carota L.), mungbean (Phaseolus aureus) and cowpea (Vigna unguiculata) (Richards, 1953; Hanks and Thorp, 1957; Sale and Harrison, 1964; Drew et al., 1965, 1971; Grant and Buckle, 1974; Chaudhry and Das, 1978, 1980; Gerard, 1980).

Restriction of seedling emergence takes place due to mechanical resistance offered by soil crust to the emerging seedlings. If the force development of young seedlings falls short of the resistance of crust penetration, the seedlings cannot push through the crust and bending of the seedlings take place just beneath the crust. Arndt (1965a) presented 6 broad cases of crust impedance, based on combinations of seedling size and cracking pattern of crust as follows: (1) Adequate cracking for fine seedlings that are flexible, but have ineffective lifting force. The cracks are sufficiently frequent and wide to permit free emergence of most of the seedlings. (2) Inadequate cracking for fine seedlings. It causes delayed and partial emergence by detouring. (3) Absence of cracks for fine seedlings. The seedlings cannot emerge unless the seed density is enough for the combined effort of seedlings to produce failure of the crust. (4) Adequate cracking for coarse seedlings that are rigid, but have effective lifting forces. (5) Inadequate cracking for free emergence of coarse seedlings. (6) Absence of cracks for coarse seedlings.

The emerging seedlings of cereals and grasses (about $1 \mathrm{~mm}$ or less in diameter) usually displace soil particles by compression and shear until the coleoptile tip is near the soil surface. At this stage if the force exerted by 
the coleoptile tip is sufficient to overcome the tensile strength of the soil crust, an inverted cone of soil is ruptured out of the crust (Taylor, 1971).

Emergence of bean seedlings decreased from 100 to $0 \%$ as the crust strength increased from 0.10 to $0.27 \mathrm{~kg} \mathrm{~cm}^{-2}$, whereas the emergence of grain sorghum seedlings decreased only when the soil strength exceeded $0.9 \mathrm{~kg}$ $\mathrm{cm}^{-2}$, but ceased above the range of $1.2-1.8 \mathrm{~kg} \mathrm{~cm}^{-2}$ (Richards, 1953; Parker and Taylor, 1965). Emergence of pearl millet and cotton seedlings decreased sharply with the increase in crust strength, whereas the emergence of guar was reduced to a lesser extent. The limiting crust strength values in a sandy loam for one seed per hole were $0.29,0.23$ and $0.72 \mathrm{~kg} \mathrm{~cm}^{-2}$ for cotton, pearl millet and guar, respectively, whereas the limiting crust strength for 2 seeds per hole was raised to 0.52 and $0.67 \mathrm{~kg} \mathrm{~cm}^{-2}$ for pearl millet and cotton, respectively (Sinha and Ghildyal, 1979; Sharma and Agarwal, 1974). The average emergence of cowpea, sorghum, mungbean and guar was $67 \%$, when the crust strength was below $1.0 \mathrm{~kg} \mathrm{~cm}^{-2}$, but it was only about $21 \%$ when the crust strength approached $3.0 \mathrm{~kg} \mathrm{~cm}^{-2}$ (Chaudhry and Das, $1980)$.

The limiting value of crust strength inhibiting emergence also depends. upon soil moisture. At a given crust strength, seedling emergence was lowest where the moisture was lowest. The other factors that influence the ability of a seed to emerge are crop species, variety, initial seed mass, soil temperature and depth of planting. Planting the seed at a greater depth reduced the chances of seedling emergence because by the time the coleoptile reaches the soil crust, the latter has become harder (Hanks and Thorp, 1957; Williams, 1956, 1963; Jensen et al., 1972; Hadas and Stibbe, 1977).

These factors add to the difficulties of establishing critical crust strength, because of the variations encountered due to the nature of plant, soil temperature, soil moisture, and water content of crust at the time of emergence.

Soil crusts have been blamed frequently for the poor rate of gaseous exchange due to its low porosity and presence of highly-orientated soil particles and for limiting the supply of oxygen to the germinating seeds. Soil crust, when dry, does not affect aeration because it develops cracks if clay is present and pore space is usually adequate if clay is not present. Domby and Kohnke (1956) reported that there was no significant difference in the rate of diffusion of air through dry silt loam having different degrees of crusting. Surface crust restricted diffusion only at low moisture tensions. The wetter the soil, the greater was the influence of crust on diffusion. A saturated soil crust could provide a very effective seal against diffusion.

\section{MANAGEMENT OF SOIL CRUST}

Soil crust is a common problem in unstable soils of arid and semi-arid regions. In these regions, the rapid drying of the soil surface enhances the rapid development of a highly rigid crust. A number of researchers have tried various management techniques to solve the problem of seedling emergence through crust to achieve proper crop stands (Carnes, 1934; 
Isiumov, 1938; Gorbunov and Bekarevitch, 1951; Hillel, 1959; Cary, 1967; Taylor, 1971; Mehta and Prihar, 1973; Cary and Evans, 1974; Prihar, 1974; Gupta and Yadav, 1978; Page and Quick, 1979).

\section{Tillage methods}

Tillage practices play an important role in controlling surface crust and affecting seedling emergence. Formation of aggregates by tillage, results in less crusting and greater seedling emergence. Aggregates formed by rototilling soils at moisture content higher than the normal working range are more stable than normally-occurring aggregates. Intensive tillage causes deterioration of soil structure and may cause severe crusting and seedling emergence problems if heavy rains followed by sunny days occur immediately after seeding.

A stratified seed bed with finer aggregates in the seed zone covered by coarser aggregates near the surface are successful in reducing both the drying rate and the adverse effects of soil crusts. The uneven surface consisting of coarse aggregates are effective in resisting the beating action of rain and minimize the hazards of surface crusts (Rathore et al., 1983a). Generally, reduced tillage systems leave an uneven and rough surface that can withstand several storms of rain before they seal and develop a hard crust (Kemper and Miller, 1974). Researchers have repeatedly concluded that minimum or no-tillage systems benefit soil structure and reduce crusting problems substantially because these systems are favourable for earthworm activity and higher microbial population at the soil surface layer (Doran, 1980). Earthworms secrete gelantinous substances that coat and stabilize soil aggregates. Stability of soil aggregates is also increased with water insoluble gummy substances secreted by organisms.

\section{Surface mulch}

Mulch that is spread on the surface of the soil prevents the formation of a crust by dissipating the energy of raindrops before they strike the soil surface (Ekern, 1950). It breaks the direct contact between soil surface and atmosphere resulting in reduction in evaporation and thus keeps the surface layer at higher moisture content for a longer period. This also helps to keep the soil strength low and facilitates emergence (Chaudhry and Das, 1978). Bennett et al. (1964) reported that on average only $10 \%$ of cotton seedlings emerged through a conventional seed bed, whereas $72 \%$ of the seedlings emerged when rows were covered with black plastic film. Straw mulching on the entire surface and strip application of organic additives have been found to be beneficial in reducing the crust and increasing the seedling emergence (Mehta and Prihar, 1973).

Although mulching reduces soil crusting, the practice has not been accepted by farmers because it frequently hampers the planting operation 
resulting in uneven emergence. The yields are sometimes reduced. Some yield reduction has been associated with the phytotoxic compounds formed during residue decomposition. A variation on this method combats this problem by using an inert mulch such as asphalt emulsion, coal, sand and pea gravel (Qashu and Evans, 1967; Ellis, 1965).

\section{Organic amendments and soil conditioners}

Soil crusting is a severe problem in weakly aggregated soils. Enhancing the stability of aggregates provides a key to the development of better techniques for reducing soil crusting. Improvement in soil structure and stability of aggregates can be achieved by using gypsum, calcium carbonate, organic amendments (farm-yard manure, crop residue, husk, etc.) and soil conditioners e.g., certain organic compounds, polyvalent salts and various synthetic polymers. The organic matter has tremendous effect on increasing the resistance of soil aggregates to the destructive impact of rain drops. Organic amendments contain ingredients that can improve the physical and chemical characteristics of soil. Their composition enable them to act as a binder for the soil particles and they also supply energy for the activity of soil organisms that can be very effective in soil aggregation. Mixing of farm-yard manure and waste products from dates and sugar beets near the soil surface increases water stable aggregates significantly (Hardan and Al-Ani, 1978; Chaudhry and Das, 1978). Plant residues (leaves, straw, roots, etc.) lose their physical strength as they are decomposed. Therefore, the place in which they were incorporated in the soil generally becomes a place of weakness. Consequently, incorporation of organic materials generally decreases crust strength as the organic matter decomposes (Kemper et al., 1974).

The addition of gypsum significantly improved aggregate stability and reduced crust strength of red-brown earth, where the original exchangeable sodium percentage (ESP) content exceeded ten. The improved aggregate stability was associated with replacement of exchangeable sodium and magnesium by calcium (So et al., 1978).

Application of synthetic polyelectrolytes and several other synthetic organic soil aggregating agents on crust-forming soils results in increased aggregates, aggregate stability, water infiltration and percolation, reduced crust and improved seedling emergence (Allison, 1952, 1956; Hedrick and Mowrey, 1952; Quastel, 1954). Allison and Moore (1956) studied the effect of VAMA (vinyl acetatemaleic acid) and HPAN (hydrolysed polyacrylonitrile) conditioners on soil aggregation, surface crusting, and moisture retention of alkali soils. Both types of conditioners were found to be effective in ameliorating soil hardness or crusting tendency. In general, the HPAN conditioner appeared to be slightly superior to the VAMA conditioners. Hemwell and Scott (1962) found that application of 4-tertiary-butyl pyrocatochol directly over the seed row caused the soil to fracture linearly over the row, thereby permitting the seedling to emerge. Application of 
water emulsion vinyl resin and water emulsion asphalt reduced crust strength and promoted germination and emergence of seedlings (Bennett et al., 1964). This was due to the increase in soil temperature by $2-3^{\circ} \mathrm{C}$ over that of the normal soil which affected the rate of germination and seedling growth. Proper application of soil conditioners does not affect the seed germination adversely.

Sulphuric acid of low concentration when applied over the seeded rows, reduced crusting in calcareous soils (Johnson and Law, 1967). Sulphuric acid was never recommended because the hazards to man and equipment were too great. Agricultural grade phosphoric acid $\left(\mathrm{H}_{3} \mathrm{PO}_{4}\right)$ reduced crusting and increased stability of a calcareous soil. It increased sugar-beet seedling emergence as well as the beet yield. The phosphorus needs of the crop were satisfied by the acid (Robbins et al., 1972). Gabriels and DeBoodt (1978) tested the effectiveness of commercially-available soil conditioners such as polyvinyl alcohol (PVA), polyacrylamide (PMA), asphalt and butadienestyrene latex over dry soil aggregates and found that these increase the stability of aggregates. The effectiveness of the soil conditioners depends on the amount sprayed per unit of area.

The high cost and limited effectiveness of most of these soil conditioners have inhibited their extensive use. DeBoodt (1975) estimated that, in case of sugar beet, an increase of $8-10 \%$ production is required to compensate for the expenses of conditioning.

\section{Measures to improve seedling emergence through the crust}

Once a crust is formed it should either be wetted frequently or should be broken mechanically. Application of water softens the crust and helps in emergence of seedlings. This method is of limited use because of the high cost and labour requirements. It is not practicable in arid and semi-arid regions where water availability is a major limiting factor.

Heinonen (1965) recommended shallow cultivation to break the crust that loosens the top soil surface and leaves it open for faster infiltration of water. But shallow cultivation cannot always be done over seeded rows because the young seedlings just below the crust may be damaged seriously. Kemper and Miller (1974) reported use of a cultipacker for breaking crust over seed rows. The cultipacker consists of a series of narrow rings supported on a tube. The arrangement allows the weight of the individual rings to press on the surface of the ground and each ring is free to follow surface contours. The rings crush the surface and break the crust. No quantitative information is available about the injury to seedlings. The rotary hoe, fingertype weeders and spring tooth harrows have also been tried. These types of equipment tend to remove soil, and there is danger of serious damage to seedlings.

A roller-type mechanical soil-crust breaker designed to break crust over seeded rows, improved emergence of sorghum and pearl millet significantly 
without any injury to the young seedlings (Awadhwal and Thierstein, 1983).

Emergence of seedlings through crust can be improved by various agronomical manipulations including selection of species and varieties with high emergence under temperature and moisture stress. Land-surface modification for planting is also a viable technique. Planting seeds on ridges improved seedling emergence because the soil environment remained suitable for germination and emergence throughout the entire emergence period (Kathore et al., 1983b).

Planting seeds in a group (hill) gives a higher emergence force than a single seed (Maranville and Clegg, 1977). Edwards (1966) found that the seedling emergence force increased from 0.36 to $0.87 \mathrm{~kg}$ when the number of seeds per hole was increased from 1 to 3. Sharma and Agarwal (1974) found higher emergence when they planted 2 seeds per hole as compared to single seed per hole. However, the seedlings emergence in cotton under one seed as well as 2 seeds per hole was zero when the crust strength was greater than $1 \mathrm{~kg} \mathrm{~cm}^{-2}$.

\section{RESEARCH NEEDS}

Considerable work has been done in order to understand the mechanism of crust formation, and its effects on seedbed characteristics. Modulus of rupture has been used widely as a measure of crust strength, but it lacks direct correlation with seedling emergence. Penetrometer techniques have been tried wherein the penetrometer is pushed from below the crust. This method is useful in the laboratory only. There is a need for a method of crust-strength evaluation that can be used in the field and should be directly related to seedling emergence.

It is possible to minimize the effects of crust by identification and development of cultivars that: (1) have a fast emergence rate; (2) exert more emerging force under temperature and moisture stress; (3) develop a thicker pushing coleoptile under stress. The crust can also be combated by: (1) developing mechanical crust-breaking equipment that does not injure the young seedlings; (2) planting seeds in hills (more than one seed per site); (3) development of seed-placement and soil-covering techniques that reduce the chances of crust formation.

Most of the existing methods for minimizing the effects of crust have several shortcomings. Research is needed to remove these drawbacks and develop new and more effective means for crust management. Improving the stability of soil aggregate is a promising solution to the soil crusting problem, but the use of soil conditioners (synthetic soil aggregating agents) is quite expensive, hence the search for relatively cheaper soil conditioners and soil additives is needed. Further improvement in crust-breaking equipment will be of great help in increasing crop establishment in crusting soils. The soil management systems need to be developed further to arrive at a technically-feasible and economically-viable solution to the problem of soil crust and seedling emergence. 


\section{REFERENCES}

Allison, L.E., 1952. Effect of synthetic polyelectrolytes on the structure of saline and alkali soils. Soil Sci., 73: 443-454.

Allison, L.E., 1956. Soil and plant responses to VAMA and HPAN soil conditioners in the presence of high exchangeable sodium. Soil Sci. Soc. Am. Proc., 20: 147-151.

Allison, L.E. and Moore, D.C., 1956. Effect of VAMA and HPAN soil conditioners on aggregation, surface crusting and moisture retention in alkali soils. Soil Sci. Soc. Am. Proc., 20: 143-146.

Arndt, W., 1965a. The nature of the mechanical impedance to seedlings by soil surface seals. Aust. J. Soil Res., 3: 75-92.

Arndt, W., 1965b. The impedance of soil seals and the forces of emerging seedling. Aust. J. Soil Res., 3: 56-58.

Awadhwal, N.K. and Thierstein, G.E., 1983. Development of rolling-type soil crust breaker. Agric. Mechan. Asia, Africa Latin America, 14: 31-34.

Barley, K.P. and Greacen; E.L., 1967. Mechanical resistance as a soil factor influencing the growth of roots and underground shoots. Adv. Agron., 19: 1-43.

Bennett, O.L., Ashley, D.A. and Doss, B.D., 1964. Methods of reducing soil crusting to increase cotton seedling emergence. Agron. J., 56: 162-165.

Busch, C.D., Rochester, E.W. and Jernigan, C.L., 1973. Soil crusting related to sprinkler intensity. Trans. ASAE, 16: 808.

Carnes, A., 1934. Soil crusts - methods of study, their strength and a method of overcoming their injury to cotton stand. Agric. Eng., 15: 167-169, 171.

Cary, J.W., 1967. Punch planting to establish lettuce and carrots under adverse conditions. Agron. J., 59: 406-408.

Cary, J.W., and Evans, D.D., 1974. Soil crusts. Techn. Bull. 214. Agric. Exp. Stn. Univ. Arizona, Tucson, AZ.

Chaudhry, K.G. and Das, D.K., 1978. Emergence of soybean, cotton and maize seedlings as influenced by crust formation in salt affected soils. J. Ind. Soc. Soil Sci., 26: 106111.

Chaudhry, K.G. and Das, D.K., 1980. Seedling emergence of summer legumes through simulated soil crust. J. Ind. Soc. Soil Sci., 28: 386-388.

Chen, Y., Tarchitzky, J., Brouwer, J., Morin, J. and Banin, A., 1980. Scanning electron microscope observations on soil crusts and their formation. Soil Sci., 130: 49-55.

Deboodt, M., 1975. Use of soil conditioners around the world. In: B.A. Stewart (Editor), Soil Conditioners. SSSA special publication series No. 7, Soil Science Society of America, Madison, pp. 1-12.

Domby, C.W. and Kohnke, H., 1956. The influence of soil crusts on gaseous diffusion. Soil Sci. Soc. Am. Proc., 20: 1-5.

Doran, J.W., 1980. Microbial changes associated with residue management with reduced tillage. Soil Sci. Soc. Am. J., 44: 518-524.

Drew, L.O., Garner, T.H. and Kish, A.J., 1965. Influence of soil crusting on seedling emergence and factors contributing to crusting. ASAE paper No. 65-149.

Drew, L.O., Garner, T.H. and Dickson, D.G., 1971. Seedling thrust vs. soil strength. Trans. ASAE, $14: 315-318$.

Edwards, F.E., 1966. Cotton seedling emergence. Mississippi Farm Res., 29 : 4-5.

Ekern, P.C., 1950. Raindrop impact as the force initiating. soil erosion. Soil Sci. Soc. Am. Proc., 15: 7-10.

Ellis, J.E., 1965. Prevention of stand losses in tomato due to soil crust formation. Am. Soc. Hort. Sci., 87: 433-437.

Epstein, E. and Grant, W.J., 1967. Soil losses and crust formation as related to some soil physical properties. Soil Sci. Soc. Am. Proc., 31: 547-550.

Epstein, E. and Grant, W.J., 1973. Soil crust formation of surface soils by raindrop impact. Ecol. Studies, 4 : 195-201. 
Evans, D.D. and Buol, S.W., 1968. Micromorphological study of soil crusts. Soil Sci. Soc. Am. Proc., 32: 19-22.

Falayi, O. and Bouma, J., 1975. Relationship between the hydraulic conductance of surface crust and soil management. Soil Sci. Soc. Am. Proc., 39: 957-963.

Gabriels, D. and DeBoodt, M., 1978. Evaluation of soil conditioners for erosion control and sand stabilization. In: W.W. Emerson, R.D. Bond and A.R. Dexter (Editors), Modification of Soil Structure, Wiley, New York, pp. 341-348.

Gerard, C.J., 1980. Emergence force by cotton seedlings. Agron. J., 72: 473-476.

Gorbunov, N.I. and Bekarevitch, N.E., 1951. The nature of the formation of a soil crust and a means of preventing it. Pochvovedeniye, 4:193-200.

Goyal, M.R., 1979. Stresses generated in soil crust by emerging dicot seedling. Ph.D. Dissertation, Ohio State University, Columbus, OH, U.S.A.

Goyal, M.R., 1982. Soil crust vs. seedling emergence: Review. Agric. Mechan. Asia, Africa Latin America, 13: 62-75.

Grant, P.M. and Buckle, J.A., 1974. Physical causes of failure in maize seedling emergence. Rodhesia. Agric. J., 74: 153-157.

Gupta, J.P. and Yadav, R.C., 1978. Soil crust formation and seedling emergence in relation to rainfall intensity and mode of sowing. J. Ind. Soil Sci. Soc., 26: 20-24.

Hadas, A. and Stibbe, E., 1977. Soil crusting and emergence of wheat seedling. Agron. J., 69 : $547-550$.

Hanks, R.J., 1960. Soil crusting and seedling emergence. Trans. 7th Int. Congr. Soil Sci., 1 : 340-346.

Hanks, R.J. and Thorp, F.C., 1957. Seedling emergence of wheat, grain sorghum and soybeans as influenced by the soil crust strength and moisture content. Soil Sci. Soc. Am. Proc., 21: 357-359.

Hardan, A. and Al-Ani, A.N., 1978. Improvement of soil structure by using date and sugar beet waste products. In: W.W. Emerson, R.D. Bond and A.R. Dexter (Editors), Modification of Soil Structure. Wiley, New York, pp. 305-308.

Hedrick, R.M. and Mowrey, D.T., 1952. Effect of synthetic polyelectrolytes on aggregation, aeration and water relationships of soil. Soil Sci., 73: 427-441.

Heinonen, R., 1965. Soil crusting and crust breaking cultivation of cereal. Lantbr. Hogsk. Medd., No. 25: 17.

Hemwell, J.B. and Scott, H.H., 1962. Use of 4-Tert Butylpyrocatechol as a fracturing aid in crusting soils. Agron. J., 54: 535-538.

Hillel, D., 1959. Studies on loessial crusts. Agric. Res. Stn. Rehovot, Bet Dagan, Israel Bull. No. 63.

Hillel, D., 1960. Crust formation in loessial soils. Trans. 7th Congr. Int. Soil Sci. Soc. Madison, WI, 1: 330-339.

Holder, C.B. and Brown, K.W., 1974. Evaluation of simulated seedling emergence through rainfall induced soil crust. Soil Sci. Soc. Am. Proc., 38: 705-710.

Hoogmoed, W.B., 1980. Development of criteria and method for improving the efficiency of soil management and tillage operations, with special reference to arid and semi-arid regions. Report No. 1. Faculty of Agriculture, The Hebrew University of Jerusalem.

Isiumov, A.N., 1938. Control of soil crust (packing). Pedology, 10: 1313-1321.

Jensen, E.H., Frelich, J.R. and Gifford, R.O., 1972. Emergence force of forage seedlings. Agron.J., 61: 635-639.

Johnson, R.C. and Law, J.B., 1967. Controlling soil crusting in sugarbeet fields by applying concentrated sulfuric acid. J. Am. Soc. Sugar Beet Technol., 14: 615-618.

Kemper, W.D. and Miller, D.E., 1974. Management of crusting soils: Some practical possibilities. In: Soil Crust. Tech. Bull. No. 214, Agric. Exp. Stn., University of Arizona, pp. 1-6.

Kemper, W.D., Evani, D.D. and Hough, H.W., 1974. Crust strength and cracking. In: Soil Crust. Tech. Bull. No. 214, Agric. Exp. Stn., University of Arizona, pp. 31-38.

Lemos, P. and Lutz, J.F., 1957. Soil crusting and some factors affecting it. Soil Sci. Soc. Am. Proc., $21: 485-491$. 
Maranvillę, J.W. and Clegg, M.D., 1977. Influence of seed size and density on germination, seedling emergence and yield of grain sorghum. Agron. J., 69: 329-330.

McIntyre, D.S., 1958a. Permeability measurement of soil crust formed by raindrop impact. Soil Sci., 85: 185-189.

McIntyre, D.S., $1958 \mathrm{~b}$. Soil splash and the formation of surface crust by raindrop impact. Soil Sci., 85: 261-266.

Mehta, A.P. and Prihar, S.S., 1973. Seedling emergence in soyabean and cotton as affected by seedbed characteristic and surface. Ind. J. Agric. Sci., 43: 45-49.

Miller, D.E. and Gifford, R.O., 1974. Modification of soil crust for plant growth. In: Soil Crust. Tech. Bull. 214. Agric. Exp. Stn. University of Arizona, pp. 7-16.

Morin, J., Benyamini, Y. and Michaeli, A., 1981. The effect of raindrop impact on the dynamics of soil surface crusting and water movement in the profile. J. Hydrol., 52: $321-335$.

Morton, C.T. and Buchele, W.F., 1960. Emergence energy of plant seedlings. Agric. Eng., 41: 428-431.

Page, E.R. and Quick, M.J., 1979. Comparison of the effectiveness of organic polymers as soil anticrusting agents. J. Sci. Food Agric., 30: 112.

Prihar, S.S., 1974. Soil crusting in dryland agriculture: Formation, avoidance and manipulation. Proc. 2nd Annu. Meet. AICRPDA, Hyderabad, India.

Parker, J.J. and Taylor, H.M., 1965. Soil strength and seedling emergence relations. 1. Soil type, moisture tension, temperature and planting depth effect. Agron. J., 57: 289-291.

Qashu, H.K. and Evans, D.D., 1967. Effect of black granular mulch on soil temperature, water content and crusting. Soil Sci. Soc. Am. Proc., 31: 429-435.

Quastel, J.H., 1954. Soil conditioners. Annu. Rev. Plant Physiol., 5: 75-92.

Rathore, T.R., Ghildyal, B.P. and Sachan, R.S., 1983a. Effect of surface crusting on emergence of soybean seedlings. I. Influence of aggregate size in the seedbed. Soil Tillage Res., 3: 111-121.

Rathore, T.R., Ghildyal, B.P. and Sachan, R.S., 1983b. Effect of surface crusting on emergence of soybean seedlings. II. Influence of tillage treatment, planting method and time of crust formation. Soil Tillage Res., 3: 233-243.

Richards, L.A., 1953. Modulus of rupture as an index of crusting of soil. Soil Sci. Soc. Am. Proc., 17: 321-323.

Robbins, C.W., Carter, D.L. and Leggett, G.E., 1972. Controlling soil crusting with phosphoric acid to enhance seedling emergence. Agron. J., 64: 180-182.

Rose, C.W., 1962. Some aspects of rainfall, radiant drying and soil factors on infiltration under rainfall into soils. J. Soil Sci., 13: 286-298.

Sale, P.J.M. and Harrison, D.J., 1964. Seedling emergence as affected by soil capping. J. Hort. Sci., 39: 147-161.

Sharma, D.P. and Agrawal, R.P., 1974. Seedling emergence behaviour of bajra, cotton and guar as affected by surface crust strength. Mysore J. Agric. Sci., 13: 400-404.

Sharma, D.P. and Agarwal, R.P., 1974. Seedling emergence behaviour of bajra, cotton relationship with the modulus of rupture in alluvial soils. J. Ind. Soc. Soil Sci., 28: 119-121.

Sinha, A.K. and Ghildyal, B.P., 1979. Emergence force of crop seedlings. Plant Soil, 51: 153-156.

So, H.B., Taylor, D.W., Yates, W.J. and McGarity, J.W., 1978. Amelioration of structurally-unstable gray and brown clays. In: W.W. Emerson, R.D. Bond and A.R. Dexter (Editors), Modification of Soil Structure. Wiley, New York, pp. 325-334.

Stout, B.A. Buchele, W.F. and Snyder, F.W., 1961. Effect of soil compaction on seedling emergence under simulated field conditions. Agric. Eng., 42: 68-71.

Tackett, J.L. and Pearson, R.W., 1965. Some characteristics of soil crusts formed by simulated rainfall. Soil Sci., 99: 407-413. 
Taylor, H.M., 1962. Seedling emergence of wheat, grain sorghum and guar as affected by rigidity and thickness of surface crust. Soil Sci. Soc. Am. Proc., 26: 431-433.

Taylor, H.M., 1971. Effects of soil strength of seedling emergence, root growth and crop yield. In: Compaction of Agricultural Soils. Am. Soc. Agric. Eng. Monogr., pp. 292305.

Williams, W.A., 1956. Evaluation of the emergence force exerted by seedling of small seeded legumes using probit analysis. Agron. J., 48: 273-274.

Williams, W.A., 1963. The emergence force of forage legume seedlings and their response to temperature. Crop Sci., 3: 472-474. 


\section{GENERAL INFORMATION}

Aims and scope. This journal is concerned with the changes in the physical, chemical and biological parameters of the soil environment brought about by soil tillage and field traffic, their effects on crop establishment, root development and plant growth, and their interactions. This implies research on selection, adaption or development of tillage systems (including reduced cultivation and direct drilling) suitable for specific conditions of soil, climate, relief, imigation and drainage, crops and crop rotations, level of fertilization, degree of mechanization, etc. In this context papers on development of soil working tools and traction devices, energy requirements and econimic aspects of tillage are most welcome. The same holds for research on soil-deformation processes, measuring methods and mathematical modelling in connection with the soilmachine-plant system. Special attention will be given to the role of tillage in weed, pest and disease control.

Publication schedule. Soil \& Tillage Research comprises six issues per annual volume of approx. 600 pages. Volume 4: 1983.

Subscriptions. Subscription price for Volume 4 is Dfl. 266.00 (approx. US \$102.35) including postage and handlıng. Send your order to your usual supplier or direct to Elsevier Science Publishers, P.O. Box 211, 1000 AE Amsterdam. The Netherlands.

Submission of articles. Manuscripts should be submitted in triplicate to the Editorial Secretariat "SoIl \& Tillage Research", P.0. Box 330, 1000 AH Amsterdam, The Netherlands.

\section{Note to Contributors}

Types of papers published in the journal

- papers reporting results of origınal research - review articles - short communications - (guest) editorials - book reviews ISTRO-INFO - reading table.

A detailed Guide for Authors is available upon request and is also printed in the first issue of each volume. You are kındly isked to cunsult this guide. Please pay special attention to the following notes:

\section{.anguage}

The official language of the journal is English.

Treparation of the text

a) The manuscript should include at the beginning an abstract of not more than 200 words.

b) It should be typewritten with double spacing and wide margins. Words to be printed in italics should be underlined.

The metric system should be used throughout.

(c) The title page should include: the title, the name(s) of the author(s) and their affiliation(s).

\section{References}

(a) References in the text should be cited as the name of the author(s). followed by the year of publication.

(b) The reference list should be in alphabetical order and on sheets separate from the text.

\section{Tables}

Tables should be compiled on separate sheets. A title should be provided for each table and all tables should be referred to in the text.

\section{Illustrations}

(a) All illustrations should be numbered consecutively and referred to in the text.

(b) Drawings should be completely lettered, the size of the lettering being appropriate to that of the drawings, but takıng into account the possible need for reduction in size (preferably not more than $50 \%$ ). The page format of the journal should be considered in designing drawings.

(c) Photographs must be of good quality, printed on glossy paper.

(d) Figure captions should be supplied on a separate sheet.

\section{Proofs}

One set of proofs will be sent to the author to be checked for printer's errors. In the case of two or more authors please indicate to whom the proofs should be sent.

\section{Reprints and page charges}

There is no page charge. Fifty reprints of each article published will be supplied free of charge. Additional reprints can be ordered on a reprint order form which is included with the proofs.

Al/ contributions will be carefully refereed for international relevance and quality. Submission of an article is understood to imply that the article is original and unpublished and is not being considered for publication e/sewhere. 


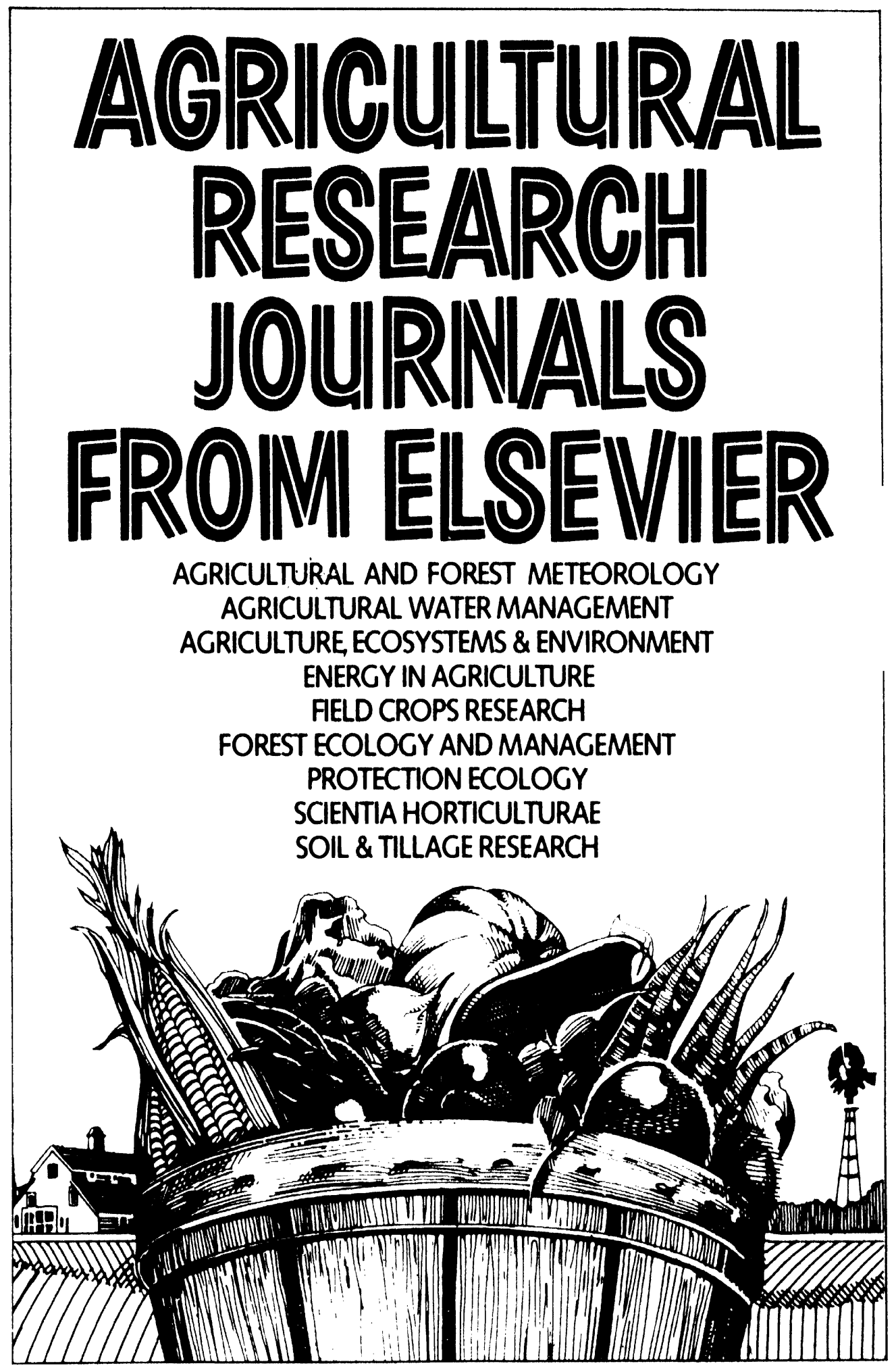

For further details contact : ELSEVIER SCIENCE PUBLISHERS P.O. Box $330 \cdot 1000 \mathrm{AH}$ Amsterdam - The Netherlands 